\title{
Effect of Land Configurations and Intercropping on Plant Height and Biomass Accumulation of Redgram under Rainfed Ecosystem
}

\author{
A. Vijayaprabhakar ${ }^{1 *}$, C. Jayanthi ${ }^{2}$, M. Balusamy ${ }^{3}$, \\ P. Malarvizhi ${ }^{4}$ and C.N. Chandrasekhar ${ }^{5}$ \\ ${ }^{1}$ Department of Agronomy, ${ }^{4}$ Department of Soil Science and Agricultural Chemistry, \\ ${ }^{5}$ Department of Crop Physiology, TNAU, Coimbatore - 641003, India \\ ${ }^{2}$ Directorate of Crop Management, TNAU, Coimbatore - 641003, India \\ ${ }^{3}$ Vanavarayar Institute of Agriculture, Manakkadavu, Pollachi, Tamilnadu-642103, India \\ *Corresponding author
}

\section{A B S T R A C T}

\section{Keywords}

Land configuration,

Intercropping,

Compartmental

Bunding, Ridges,

furrow and broad

bed furrow

Article Info

Accepted:

17 June 2018

Available Online:

10 July 2018
The field experiment was conducted during September, 2017 to March, 2018 in Agricultural Research Station, Virinjipuram, Tamil Nadu Agricultural University with different land configurations under rainfed ecosystem to understand the redgram growth and yield response. The experiment was laid out in split plot design with three main factors as land configurations $\mathrm{L}_{1}$ - Compartmental bunding, $\mathrm{L}_{2}$ - Broad Bed Furrow and $\mathrm{L}_{3}$ Ridges and furrow and seven sub factors as $S_{1}$ - Redgram + Blackgram (4:5), $S_{2}$ - Redgram + Greengram (4:5), $S_{3}$ - Redgram + Cowpea (4:5), $S_{4}$ - Redgram + Groundnut (4:5), $S_{5}$ Redgram + Sesame (4:5), $S_{6}-$ Redgram + Cotton (4:4) and $S_{7}-$ Redgram sole cropping and were replicated thrice. The higher redgram plant height $(192 \mathrm{~cm})$, leaf area index (3.24), dry matter production $(1760 \mathrm{~kg} / \mathrm{ha})$ and redgram grain yield $(668 \mathrm{~kg} / \mathrm{ha})$ was recorded with the $\left(\mathrm{L}_{3}\right)$ ridges and furrow method of sowing. Among the intercropping system, higher redgram plant height $(179 \mathrm{~cm})$ and dry matter production $(1718 \mathrm{~kg} / \mathrm{ha})$ was recorded in redgram + blackgram intercropping system. The lowest redgram plant height, leaf area index, dry matter production and redgram grain yield was recorded in redgram + cotton $\left(\mathrm{S}_{6}\right)$ intercropping system.

\section{Introduction}

Intercropping is one of the best agronomical options to minimize risk and it will be act as insurance against main crop failure in the vast rainfed tracts in the country (Sankaranarayanan et al., 2010), it lead to farmers profit and subsistence oriented, energy-efficient and sustainable venture (Faroda et al., 2007). The main concept of intercropping is to get increased total productivity per unit area and time, besides equitable and judicious utilization of land resources and farming inputs including labor. A careful selection of crops can reduce the mutual competition for moisture and nutrients to a considerable extent, i.e., by including fast growing early maturing crop with a slow growing, late maturing one. Redgram is a late maturing, tall growing and wide spaced crop 
with deep root system, which makes it suitable for intercropping. Besides, the growth of redgram is very slow in the early stage, during which time the more rapidly growing short duration and short statured crops like greengram and also taller crops like pearlmillet and sesamum can be conveniently intercropped to utilize the natural resources most efficiently in the early stages of pigeonpea.

Several studies already conducted with redgram based intercropping as one row or two rows of redgram with more number of intercrop rows, but, there is no systematic work on intercropping with increased number of redgram rows $(>2)$ in replacement series and its effect on redgram plant height and biomass production in rainfed condition. Rainfed areas production completely depends on natural precipitation and the problem is low moisture in the root zone during the dry season (Hulihall and Patil, 2006), which leads to reduction of productivity by 35 to 40 percentage lesser than irrigated farming. To conserve the soil moisture, land configurations such as broad bed furrow, compartment bunding, set furrow cultivation and ridges and furrow etc, practices mainly aimed to conservation rain water and ensure uniform distribution of moisture in the inter-terraced area. Hence, the investigation was aimed to identify the land configuration to increase soil moisture conservation and understand the growth response of redgram with different intercropping systems.

\section{Materials and Methods}

The field experiment was conducted during September, 2017 to March, 2018 in Agricultural Research Station, Virinjipuram, Tamil Nadu Agricultural University at $12^{\circ} 5^{\prime}$ $\mathrm{N}$ and $79^{\circ} \mathrm{E}$, to study the different redgram based intercropping system with varied land configurations under rainfed ecosystem to appraise the redgram growth and yield response with different intercrops. The soil of the experimental field is sandy clay loam with the $\mathrm{pH}$ of 7.8 , bulk density of $1.58 \mathrm{~g} / \mathrm{cm}^{-3}$, organic matter content of $1.335 \mathrm{~g} / \mathrm{kg}$, total $\mathrm{N}$ content of $285 \mathrm{~kg} / \mathrm{ha}$, total $\mathrm{P}$ content of 15.2 $\mathrm{kg} / \mathrm{ha}$ and total $\mathrm{K}$ content of $276 \mathrm{~kg} / \mathrm{ha}$. Total rainfall during the crop period was $655.0 \mathrm{~mm}$.

The experiment was laid out in Split Plot Design with three main factors of land configurations $\mathrm{L}_{1}$ - Compartmental bunding, $\mathrm{L}_{2}$ - Broad bed furrow and $\mathrm{L}_{3}-$ Ridges and furrow and seven sub factors as $\mathrm{S}_{1}$ - Redgram + Blackgram (4:5), $\mathrm{S}_{2}$ - Redgram + Greengram (4:5), $\mathrm{S}_{3}$-Redgram + Cowpea (4:5), $\mathrm{S}_{4}$ - Redgram + Groundnut (4:5), $\mathrm{S}_{5}$ Redgram + Sesame (4:5), $\mathrm{S}_{6}$-Redgram + Cotton (4:4) and $S_{7}$-redgram sole crop were replicated thrice. Test varieties were Co $(\mathrm{Rg})$ 7, Co 6, Co 8, VBN 1, TMV 13, TMV 7 and Co 14 used for redgram, blackgram, greengram, cowpea, groundnut, sesame and cotton crops respectively. After main field preparation land configurations are were made manually with gross plot size of $8.6 \mathrm{~m} \times 3.8$ $\mathrm{m}\left(32.68 \mathrm{~m}^{2}\right)$ and net plot size of $7.8 \mathrm{~m} \times .3 .0$ $\mathrm{m}\left(23.4 \mathrm{~m}^{2}\right)$. The compartmental bunding made by bunds around the plot to favour the infiltration of rain water without get off. In Broad bed furrow, beds were formed manually with the width of $150 \mathrm{~cm}$ bed and $30 \mathrm{~cm}$ furrow with $15 \mathrm{~cm}$ depth and height of $15 \mathrm{~cm}$ for both main and intercrops. Ridges \& furrow were opened with the spacing of $45 \mathrm{~cm}$ for redgram and cotton and $30 \mathrm{~cm}$ for blackgram, greengram, cowpea, groundnut and sesame and sowing was done by dippling method. All the cultural practices for respective crops under rainfed condition were followed as per TNAU crop production guide. After crop establishment, five plants at random from each plot were selected and tagged for the purpose of recording morphological and yield parameters. Plant height was recorded from the ground level to the growing tip of the main shoot at harvest stage of crops. Plant samples for dry matter studies were collected at harvest 
stage. The collected samples were air dried and then oven dried at $65 \pm 5^{0} \mathrm{C}$ till it reached a constant weight. The total dry matter production (DMP) was expressed in $\mathrm{kg} / \mathrm{ha}$. The data were subjected to statistical scrutiny as per the procedure given by Gomez and Gomez (1984). Wherever, the treatment differences were found as significant ( $\mathrm{F}$ test) critical differences were worked out at 5 per cent probability level and the values were furnished in the respective tables.

\section{Results and Discussion}

Effect of land configurations and intercropping on redgram plant height

Among the different land configurations, ridges and furrow $\left(\mathrm{L}_{3}\right)$ method of sowing recorded higher redgram plant height of 192 $\mathrm{cm}$. This was on par with compartmental bunding $\left(\mathrm{L}_{1}\right)$ method of sowing. The lower redgram plant height was recorded in broad bed furrow sowing $(158 \mathrm{~cm}$ ) (Table 1). In different intercropping, redgram pure crop recorded maximum plant height of $183 \mathrm{~cm}$. This was on par with redgram plant height grown with groundnut $\left(\mathrm{S}_{4}\right)$, greengram $\left(\mathrm{S}_{2}\right)$ and blackgram $\left(S_{1}\right)$ intercropping. This was followed by intercropping of cowpea $\left(\mathrm{S}_{3}\right)$ and sesame $\left(\mathrm{S}_{5}\right)$ in redgram plant height. The lowest redgram plant height $(156 \mathrm{~cm})$ was recorded with cotton $\left(\mathrm{S}_{6}\right)$ intercropping (Table $1)$.

Figure.1 Effect of land configurations and intercropping on redgram plant height and dry matter production

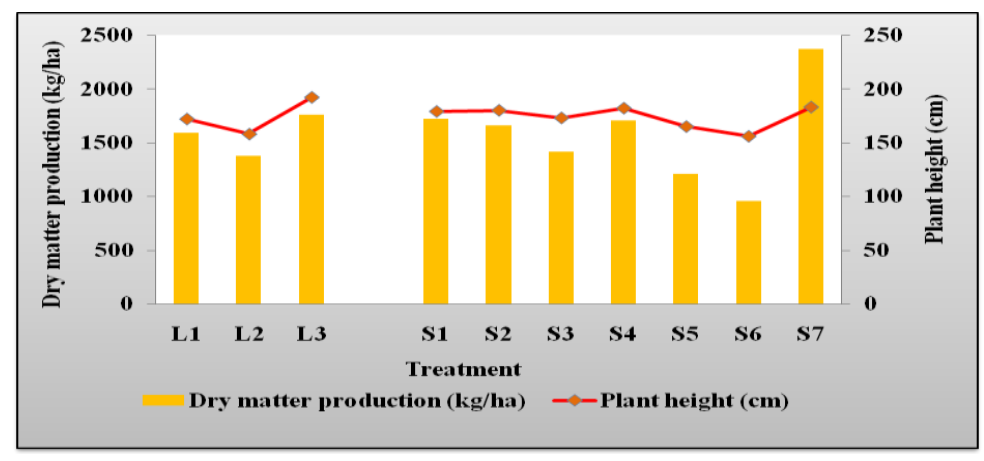




\begin{tabular}{|c|c|c|c|c|}
\hline \multicolumn{5}{|c|}{ Table. 1 Effect of land configurations and intercropping on redgram plant height } \\
\hline Treatments & \multicolumn{4}{|c|}{ Plant height $(\mathrm{cm})$} \\
\hline \multirow{2}{*}{ Intercropping } & \multicolumn{4}{|c|}{ Land configuration } \\
\hline & $\mathrm{L}_{1}$ & $\mathrm{~L}_{2}$ & $\mathrm{~L}_{3}$ & Mean \\
\hline$S_{1}-R G+B G(4: 5)$ & 177 & 163 & 197 & 179 \\
\hline$S_{2}-R G+G G(4: 5)$ & 178 & 165 & 199 & 180 \\
\hline $\mathrm{S}_{3}-\mathrm{RG}+\mathrm{CP}(4: 5$ & 174 & 158 & 186 & 173 \\
\hline $\mathrm{S}_{4}-\mathrm{RG}+\mathrm{GN}(4: 5)$ & 179 & 166 & 201 & 182 \\
\hline $\mathrm{S}_{5}-\mathrm{RG}+\mathrm{SM}(4: 5)$ & 165 & 150 & 180 & 165 \\
\hline $\mathrm{S}_{6}-\mathrm{RG}+$ Cotton $(4: 4)$ & 154 & 137 & 176 & 156 \\
\hline $\mathrm{S}_{7}-\mathrm{RG}$ (Sole crop) & 180 & 166 & 202 & 183 \\
\hline \multirow[t]{2}{*}{ Mean } & 172 & 158 & 192 & \\
\hline & $\mathrm{L}$ & $\mathrm{S}$ & L at S & $S$ at $L$ \\
\hline SEd & 7.8 & 4.5 & 10.6 & 7.8 \\
\hline $\mathrm{CD}(\mathrm{P}=0.05)$ & 21.8 & 9.1 & NS & NS \\
\hline
\end{tabular}

\begin{tabular}{ccc}
\hline \multicolumn{3}{c}{ Land configurations } \\
\hline $\begin{array}{c}\mathrm{L}_{1}-\text { Compartmental } \\
\text { bunding }\end{array}$ & $\mathrm{L}_{2}-$ Broad bed and \\
Furrow (BBF) & $\mathrm{L}_{3}-$ Ridges and furrow \\
\hline $\mathrm{RG}$ - Redgram; BG - Blackgram; GG - Greengram; CP - Cowpea; GN - & Groundnut; SM - Sesame \\
\hline
\end{tabular}

\begin{tabular}{|c|c|c|c|c|}
\hline $\begin{array}{l}\text { Effect of land configur: } \\
\text { Treatments }\end{array}$ & \multicolumn{4}{|c|}{ Dry matter production $(\mathrm{kg} / \mathrm{ha})$} \\
\hline \multirow{2}{*}{ Intercropping } & \multicolumn{4}{|c|}{ Land configuration } \\
\hline & $\mathrm{L}_{1}$ & $\mathrm{~L}_{2}$ & $\mathrm{~L}_{3}$ & Mean \\
\hline$S_{1}-R G+B G(4: 5)$ & 1741 & 1509 & 1902 & 1718 \\
\hline$S_{2}-R G+G G(4: 5)$ & 1654 & 1441 & 1886 & 1661 \\
\hline$S_{3}-R G+C P(4: 5$ & 1377 & 1286 & 1585 & 1416 \\
\hline $\mathrm{S}_{4}-\mathrm{RG}+\mathrm{GN}(4: 5)$ & 1790 & 1469 & 1852 & 1704 \\
\hline $\mathrm{S}_{5}-\mathrm{RG}+\mathrm{SM}(4: 5)$ & 1197 & 1078 & 1339 & 1205 \\
\hline$S_{6}-R G+$ Cotton $(4: 4)$ & 953 & 855 & 1066 & 958 \\
\hline $\mathrm{S}_{7}-\mathrm{RG}$ (Sole crop) & 2419 & 1996 & 2693 & 2369 \\
\hline \multirow[t]{2}{*}{ Mean } & 1590 & 1376 & 1760 & \\
\hline & $\mathrm{L}$ & $\mathrm{S}$ & $\mathrm{L}$ at $\mathrm{S}$ & $\mathrm{S}$ at $\mathrm{L}$ \\
\hline SEd & 78 & 51 & 113 & 89 \\
\hline $\mathrm{CD}(\mathrm{P}=0.05)$ & 217 & 104 & NS & NS \\
\hline
\end{tabular}

Land configurations

$\begin{array}{ccc}\mathrm{L}_{1}-\text { Compartmental } & \mathrm{L}_{2}-\text { Broad bed and } \\ \text { bunding } & \text { Furrow (BBF) } & \mathrm{L}_{3}-\text { Ridges and furrow }\end{array}$

RG - Redgram; BG - Blackgram; GG - Greengram; CP - Cowpea; GN -

Groundnut; SM - Sesame 
Effect of land configurations and intercropping on redgram plant height

The plant height of redgram in ridges and furrow was increased by 10.4 percent higher than compartmental bunding method of sowing and 34.0 per cent higher than broad bed furrow method of sowing (Fig. 1). In the same way, higher plant height in ridges and furrow was reported by Deshmukh and Patel (2013) in pearl millet and Singh et al., (2013) in sorghum crops. This was due to maintaining the favorable moisture condition for relatively longer duration in ridges and furrow method of sowing (Parihar et al., 2010; Singh et al., 2013) compared to compartmental bunding and broad bed furrow method of sowing.

The redgram plant height in groundnut intercropping was $4.7,8.9$ and 13.6 per cent higher than cowpea, sesame and cotton intercropping (Fig. 1). The redgram plant height $(156 \mathrm{~cm})$ in cotton $\left(\mathrm{S}_{6}\right)$ intercropping was reduced by 17.0 per cent compared to redgram sole crop. This results are conformity with the findings of Shivran and Ahlawat (2000), who reported that plant height in sole redgram and redgram intercropped with blackgram, did not differ significantly due to absence of competition between the crops and it favored to increased redgram plant height, on the other hand taller plants of sesame, finger millet (Srichandan and Mangaraj, 2015) and cotton (Junejo, 2006) might have depressed the growth of associated pigeonpea where the growth rate was usually lower during initial growth stages.

\section{Effect of land configurations and intercropping on redgram dry matter production}

In ridges and furrow method of sowing dry matter production of redgram increased by 9.6 percent higher than compartmental bunding method of sowing and 21.8 per cent higher than broad bed furrow method of sowing (Fig. 1). These results are in line with findings of Deshmukh and Patel (2013), Karimvand et al., (2013), Ambika et al., (2017) and Bhople et al., (2018) in cluster bean, sorghum, pearlmillet, cowpea, cotton and sunflower respectively. The ridges and furrow modification in surface configuration aided in conservation rain water and its availability for longer duration, mini barriers in run-off of water and increased moisture improved the availability of nutrients as well as nutrient uptake (Bhople et al., 2018). This in turn might have helped in the rapid cell division and multiplication and resulted in expansion of leaf area with increased chlorophyll content. As a result increased photosynthetic rate might have increased the supply of carbohydrates to the plants which in turn increased the vertical and lateral growth leading to higher dry matter accumulation (Saki Nejad, 2011).

The redgram dry matter production in blackgram intercropping was 17.5, 29.8 and 44.2 per cent higher than cowpea, sesame and cotton intercropping system with redgram (Fig. 1). The lower redgram dry matter production was recorded with cowpea $\left(\mathrm{S}_{3}\right)$ sesame $\left(\mathrm{S}_{5}\right)$ and cotton $\left(\mathrm{S}_{6}\right)$ intercropping (Table 2). Similar findings were reported by Soniya (2014) in redgram. This was due to the absence of competition between redgram and intercrops of blackgram, greengram and groundnut, which in turned to maximum dry matter production by enhanced plant height, number of branches and leaves, leaf area index and crop growth rate (Srichandan and Mangaraj, 2015).

From the results and discussion, it can be concluded that, among the different land configurations, ridges and furrow method of sowing $\left(\mathrm{L}_{3}\right)$ recorded higher redgram plant height and dry matter production. In various 
intercropping system, redgram intercropping with blackgram $\left(S_{1}\right)$, groundnut $\left(S_{4}\right)$ and greengram $\left(S_{2}\right)$ produced higher plant height and dry matter production without affecting the growth of redgram.

\section{References}

Allolli, T.B., Hulihalli, U.K. and Athani, S.I. 2008. Influence of in situ moisture conservation practices on the performance of dryland cluster bean. Karnataka j. Agric. Sci., 21(2): 250252.

Ambika, V., Yadahalli, G.S., Chittapur, B.M., Kulkarni, S., Vidyavathi, G., Yadahalli and Malakannavar, S.M. 2017. Effect of different land configurations and nutrient levels on growth, yield, nutrient uptake and economics of bt cotton. Green farming, 8 (6): 1280-1283.

Bhople, K.J. Kubde, Bharti Tijare and Godavari Gaikwad. 2018. Impact of Land Configurations and Nutrient Levels on Growth and Yield of Sunflower under Rainfed Condition. Int.J.Curr.Microbiol.App.Sci. $\quad 7(01)$ : 363-368.

Deshmukh, S.P. and Patel, J.G. 2013.Influence of Non-monetary and Low Cost Input in Sustainable Summer Pearlmillet (Pennisetum Glaucum L.) Production. International Journal of Agriculture and Food Science Technology, 4 (6): 579-588.

Faroda, A.S., Joshi, N.L., Singh, R and Saxena, A. 2007. Resource management for sustainable crop production in arid zone. Indian $J$. Agron., 52(3): 181-93.

Gomez, K.A. and A.A. Gomez. 1984. Statistical procedures for agricultural research. II Ed., John Wiley and Sons, New York. pp.381.

Hadvani, R.G., Ahlawat, R.P.S. and Trivedi,
S.J. 1993. Effect of methods of sowing and levels of sulphur on growth and yield of groundnut. Indian J. Agron., 38 (2): 325-327.

Hughes, G., Kestinge, J.D.H. and Scott, S.P. 1979. Pigeonpea as a dry season crop in Trinidad, West Indies II. Interception and utilization of solar radiation. Trop. Agric., 56: 371-374.

Hulihalli, U.K. and Patil, V.C. 2011. Soil Moisture Content, Yield and Wateruse Efficiency of Cotton in Relation to in-situ Moisture Conservation Practices and Organic Manures under Rainfed Conditions. Annals of Arid Zone, 50(1): 27-35.

Junejo, G.Q. 2006. Yield influence of intercropping cotton with pigeon pea. Dept. of Agronomy, Sindh Agriculture Univ., Tandojam (Pakistan).

Karimvand, P.N., Nejad, T.S. and Shokohfarn, A.R. 2013. The effects of basin, ridge and furrow planting methods on yield components of cowpeas at different irrigation levels. Intl. J. Agri Crop Sci., 6 (20): 14071412.

Kumar, S., Singh, R.C. and Kadian, V.S. 2003. Production potential of pigeonpea (Cajanus cajan) and greengram (Phaseolus radiates) intercropping patterns in Semi-arid tract of Haryana. Indian J. Agron., 48(4): 259-262.

Nejad, S.T. 2011. Effect of drought stress on stomata resistance changes in corn. Journal of American Science, 7(9):2731.

Parihar, C.M. K.S. Rana and Kantwa, S.R. 2010. Nutrient management in pearlmillet (Pennisetum glaucum)mustard (Brassica juncea) cropping system as affected by land configuration under limited irrigation. Indian J. Agron., 55 (3): 191-196.

Prakash, O.M. and Bhushan, L.S. 2000. 
Productivity and economics of pigeonpea (Cajanus cajan) and castor (Ricinus communis) based intercropping systems. Indian Journal of Soil Conservation. 28(2): 147-150.

Sankaranarayanan, K., Praharaj, C.S., Nalayini, P., Bandyopadhyay, K.K and Gopalkrishna, N. 2010. Legume as companion crop for cotton. Journal of Cotton Research Development. 24(1): 115-126.

Shivran, D.R. and Ahlawat, I.P.S. 2000. Effect of cropping systems and fertilizers on pigeonpea and wheat in pigeonpea wheat sequence. Indian $J$. Agron., 45: 669-676.

Singh, P., Sumeriya, H.K. and Kaushik, M K. 2013. Effect of in-situ soil moisture conservation practices and its interaction with nutrients in yield, quality and economics of sorghum
[Sorghum bicolor (L.) Moench]. Advance Research J. of crop Improvement 4(2): 88-92.

Somasundaram, E., Jauhar Ali. A., Manoharan M.L. and Arokiaraj, A. 2000. Response of crops to different land management practices under sodic soil conditions, Indian J. Agron., 45: 92-96.

Soniya. 2014. Evaluation of different crops and intercropping systems alternate to cotton in rainfed alfisols. M.Sc. (Ag) Thesis, Acharya N.G. Ranga agricultural university, Hyderabad.

Srichandan, S. and Mangaraj, A.K. 2015. Growth, Yield and Yield Attributes of Pigeon Pea in Rainfed Uplands of Western Central Table Land Zone of Odisha. International Journal of Research in Agriculture and Forestry, 2(9): 10-13.

\section{How to cite this article:}

Vijayaprabhakar, A., C. Jayanthi, M. Balusamy, P. Malarvizhi and Chandrasekhar, C.N. 2018. Effect of Land Configurations and Intercropping on Plant Height and Biomass Accumulation of Redgram under Rainfed Ecosystem Int.J.Curr.Microbiol.App.Sci. 7(07): 2471-2477. doi: https://doi.org/10.20546/ijcmas.2018.707.289 